\title{
PROGERIA AND ATHEROSCLEROSIS
}

BY

\author{
A. J. KEAY, M. F. OLIVER and G. S. BOYD \\ From the Royal Hospital for Sick Children, Edinburgh, the Department of Cardiology, \\ Royal Infirmary, Edinburgh, and the Department of Biochemistry, University of Edinburgh
}

(RECEIVED FOR PUBLICATION APRIL 26, 1955)

The term 'progeria' was first used by Gilford in 1902 to describe a condition of premature senility occurring in children, although Hutchinson had reported the first case in 1886 under the title of 'Congenital Absence of the Hair and Mammary Glands'. The fully developed picture is one of retarded development combined with premature old age, the child rapidly becoming an old, wizened dwarf. Death occurs most commonly in the second decade. Both sexes are affected and there is no familial tendency. The aetiology of progeria remains obscure, although the anterior pituitary gland has been implicated by some authors. Thomson and Forfar (1950) reviewed the literature and found 18 typical and an equal number of atypical cases which did not show the complete picture. They described a case of their own and since then five further cases have been reported (Rossi, 1951; Cooke, 1953; Doub, 1953; Atkins, 1954; Plunkett, Sawtelle and Hamblen, 1954).

A further case of progeria is described. In this child, who was only temporarily resident in the area, some of the endocrine functions have been assessed and a study has been made of the circulating lipid and lipoprotein patterns.

\section{Case Report}

P.M. was 3 years old when referred to the Royal Hospital for Sick Children, Edinburgh, because of baldness. He is the third child of healthy, unrelated parents and was delivered spontaneously one month before the expected date, after a normal, uneventful pregnancy. His birth weight was $2.86 \mathrm{~kg}$. (6 lb. $5 \mathrm{oz}$.). Breast feeding was successfully established and maintained for five months.

He gained weight normally for about six months, but thereafter his weight gain became progressively slower, although he never lost weight. From the age of about 4 months his mother noticed that he tended to be blue about the lips. He sat at 7 months, crawled at 11 months, walked at 15 months and the first tooth was cut at 1 year. Speech developed normally during the second year and he has always been intelligent and in some ways precocious. His appetite has been variable, but on the whole he eats less than other children. He sleeps with his eyes partly open. During the second year his hair, which had grown normally until then, became thinner and the scalp veins were more prominent. Apart from an acute respiratory infection when 2 years old he has been well and has had none of the infectious diseases; he has never played much with other children, but is in no way distressed by exertion.

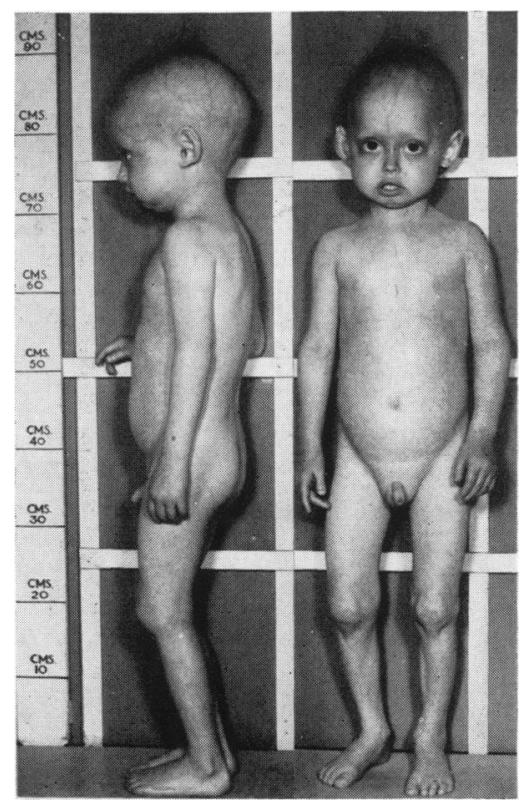

FIG. 1.-The characteristic facies and 'horse-riding' stance.

His parents are well developed physically. The first child of their marriage died at 6 months of age from 'congenital heart disease', but a post-mortem examination was not carried out. The second and fourth children, now aged 5 years and 1 year, are well and normally developed.

When examined at the age of 3 years, P.M. presented the characteristic picture of progeria (Figs. 1 and 2). His measurements are presented in Table 1. He was a friendly little fellow and showed a keen interest in his 
TABLE 1

MEASUREMENTS OF PRESENT CASE COMPARED WITH THE AVERAGE FOR A BOY OF 3 YEARS

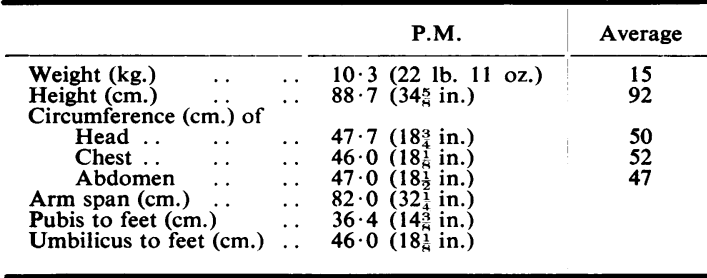

surroundings, ready to copy any new actions he saw and asking questions constantly. His voice was rather highpitched and at times difficult to follow, but his vocabulary was good and his power of conversation advanced for his age. He was happiest when occupied, particularly with mechanical toys, and did not appear unduly irascible. He could run quite well, but preferred to walk slowly. Sometimes, instead of joining in games with other children, he stood by watching with an aloof,

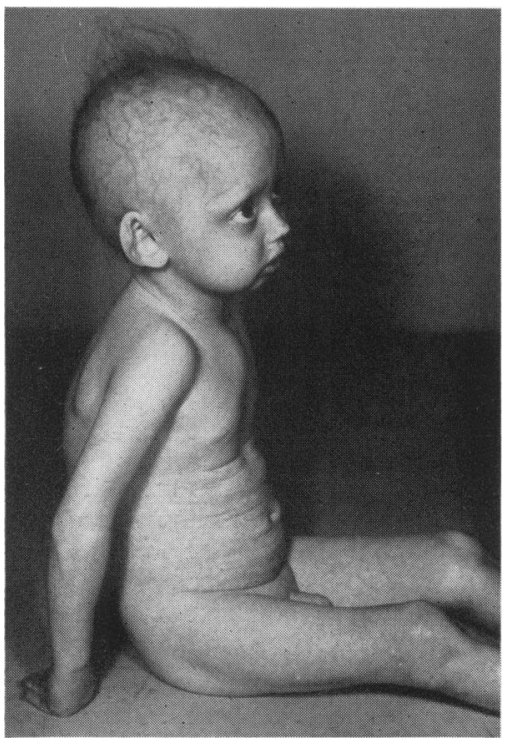

FIG. 2.-The scanty hair, the abnormal ears and the pigmentation of the skin.

superior demeanour. When standing, there were frequent restless movements of the hands and wrists with a rocking movement from one foot to the other. Incomplete extension of the hip and knee joints together with failure of full extension of the elbow gave the typical 'horse-riding' stance.

The skin generally was dry and lacked the normal elasticity, and there was little or no subcutaneous fat except over the abdomen and in the cheeks. There were no cutaneous xanthomatous lesions, but a reticulated brown pigmentation was present over the trunk and neck

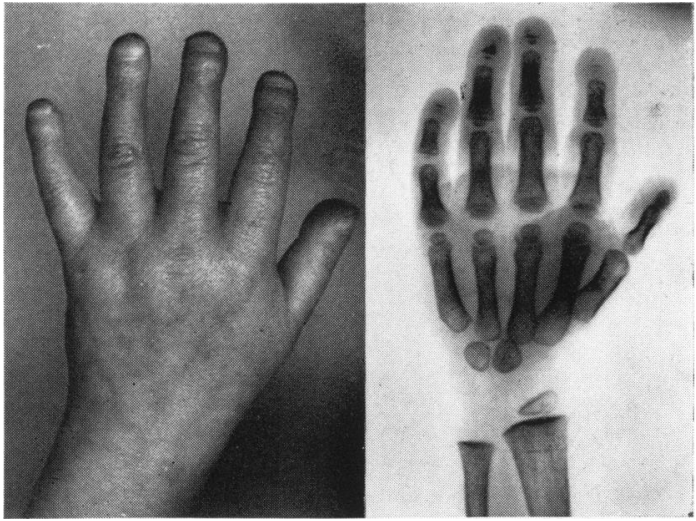

Fig. 3.-Hypoplasia of the terminal phalanges.

and there were some freckles on the face (Fig. 2). The nipples were not abnormal.

The scalp had only a few wispy hairs. The skull appeared large in relation to the face, and the anterior fontanelle and sutures were not closed; a continuous souffle was heard on auscultation in both temporal areas. There were no eyebrows and only scanty eyelashes; the eyes were large and prominent and there was no arcus senilis and no epicanthic fold. The nose was narrow at the bridge and generally thin, yet in contrast the cheeks were relatively plump. The lips were normal, but the surrounding skin had a bluish tinge not observed elsewhere. The mandible was poorly developed and there was a large dimple at the point of the chin; there were 16 teeth which were in good condition and not unduly crowded. The ears were prominent with a large external meatus and poorly formed lobules.

The limbs were thin, bringing the joints, particularly the knees, into prominence. The nails were complete but short in relation to their breadth, the whole terminal phalanx being poorly developed (Fig. 3). The thorax had a narrow inlet but the clavicles were palpable. The heart sounds were normal and no murmurs were heard. Blood pressure was $110 / 64 \mathrm{~mm}$. Hg. There was no palpable abnormality of the peripheral arteries and the retinal vessels appeared normal on ophthalmoscopy.

The abdomen was prominent and the overlying skin felt abnormally firm. It was not possible to palpate the liver, spleen or kidneys. The external genitalia were normal for a boy of his age and both testicles were in the scrotum. Physical examination of the respiratory and central nervous systems showed no abnormality. There were no palpable glands.

Radiology. In the skull (Fig. 4) there was no abnormality of the sella turcica. Slight gaping of the posterior sutures was observed with sutural bone formation in the posterior coronal and right lambdoidal sutures. There was moderate hypoplasia of the maxillae and marked hypoplasia of the mandible both in the horizontal and ascending rami; the second deciduous molars were unerupted. 
Both clavicles were attenuated, tapering off at the extremities. Metaphyseal angulation of the proximal

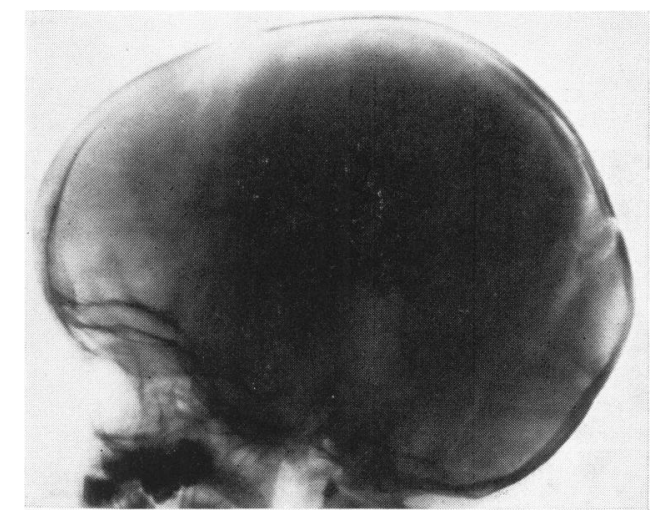

FIG. 4.-A normal sella turcica, an open fontanelle and open lambdoidal sutures.

ends of the radii was present and there was hypoplasia of the terminal phalanges of both hands (Fig. 3).

The lumbosacral spine was bifid. There was marked coxa valga with bowing of the femora (Fig. 5). Moderate generalized osteoporosis was noted, the ossification

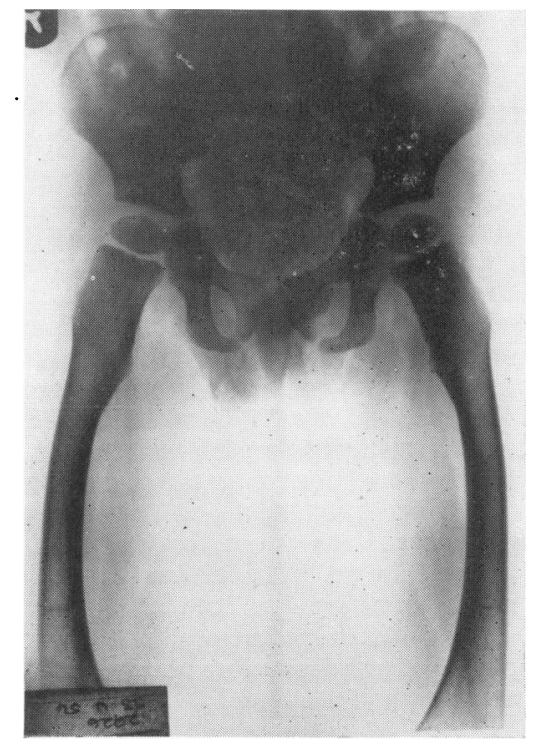

FIG. 5.-The coxa valga and bowing of the femora.

generally being average for the age. There was no pulmonary lesion but slight generalized enlargement of the heart.

Electrocardiography. Electrocardiography showed sinus arrhythmia, and a heart rate 107 per minute; the
PR interval was $0.10 \mathrm{sec}$. The standard, unipolar limb and six $V$ chest leads were normal before and after exercise.

Urine. Specific gravity was 1,030 maximum and 1,003 minimum. No albumin or reducing substance was present. The total amino-acid nitrogen content was $27.4 \mathrm{mg}$. \%. A one-way chromatogram was normal. Creatine excretion per 24 hours was $101 \mathrm{mg}$., and creatinine per 24 hours, $143 \mathrm{mg}$.

Blood. Haemoglobin was $10.65 \mathrm{~g}$. \%, red blood cells, $4 \mathrm{~m} . / \mathrm{c} . \mathrm{mm}$. The P.C.V. was $36.0 \mathrm{~mm}$. The urea nitrogen level was $8 \mathrm{mg}$. \%. The serum creatinine level was $0.3 \mathrm{mg}$. \%, serum sodium, $316 \mathrm{mg}$. \%, serum chlorides, $582 \mathrm{mg}$. \%, serum potassium, $23.4 \mathrm{mg}$. \%. The serum $\mathrm{CO}_{2}$-combining power was $57 \mathrm{vol}$. \%. The serum calcium level was $10.9 \mathrm{mg}$. $\%$, the serum inorganic phosphorus, $5.0 \mathrm{mg}$. \%, the serum alkaline phosphatase, 14 King-Armstrong units. Serum proteins totalled 7.4 g. $\%$ (albumin, 5.4 g. \%, globulin, 2 g. \%).

Circulating Lipids and Lipoproteins. These are given in Table 2.

TABLE 2

\section{CIRCULATING LIPIDS AND LIPOPROTEINS}

\begin{tabular}{|c|c|c|}
\hline & Patient & $\begin{array}{l}\text { Means of Normal } \\
\text { 3-year-old } \\
\text { Children }\end{array}$ \\
\hline $\begin{array}{l}\text { Plasma total cholesterol (mg. \%) } \\
\text { (Sperry and Webb, 1950) }\end{array}$ & $\begin{array}{c}225-240 \\
\text { (Average } 230 \text { ) }\end{array}$ & 149 \\
\hline $\begin{array}{l}\text { Plasma total cholesterol : phos- } \\
\text { pholipid ratio (C/P ratio) } \\
\text { (lipid phosphorus by the } \\
\text { method of Allen, } 1940 \text { ) }\end{array}$ & $\begin{array}{c}0.99-1 \cdot 30 \\
\text { (Average } 1 \cdot 07 \text { ) }\end{array}$ & $0 \cdot 74$ \\
\hline $\begin{array}{l}\text { Concentration of cholesterol } \\
\text { attached to the alpha lipo- } \\
\text { protein fraction expressed } \\
\text { as a ratio to that attached } \\
\text { to the beta lipoprotein frac- } \\
\text { tion (Boyd, 1954) .. }\end{array}$ & $11: 89$ & $30: 70$ \\
\hline
\end{tabular}

Endocrine Function Tests. The ratio of day to night excretion of urine and the water test according to the criteria for children of Talbot, Sobel, McArthur and Crawford (1952) were both normal.

Eosinophils numbered 208/c.mm., and four hours after $15 \mathrm{mg}$. A.C.T.H. intramuscularly, 34/c.mm. Urinary 17-ketosteroids were $0.62 \mathrm{mg} . / 24$ hours and $0.87 \mathrm{mg} .24$ hours. Free formaldehydogenic steroids were 0.145 and $0.095 \mathrm{mg} . / \mathrm{m}^{2}$ (Lloyd and Lobotsky, 1950).

Glucose Tolerance Test. This test after $20 \mathrm{~g}$. of glucose gave a fasting level of $93 \mathrm{mg}$. \%, at half an hour, $129 \mathrm{~g}$., at one hour, $126 \mathrm{mg}$. \%, at one and a half hours, $107 \mathrm{mg}$. \%, at two hours, $102 \mathrm{mg}$. \%. No glycosuria was noted during the test.

Radio-active Iodine Test. After 10 microcuries the following results were obtained:

$$
\begin{array}{rccr}
0-8 \text { hour excretion } & \ldots & \ldots & 43 \cdot 4 \% \\
8-24 \text { hour excretion } & \ldots & \ldots & 12 \cdot 7 \% \\
24-48 \text { hour excretion } & \ldots & \ldots & 2 \cdot 3 \% \\
0-48 \text { hour excretion } & \ldots & \ldots & 58 \cdot 4 \%
\end{array}
$$

T. index $=7 \cdot 8 \%$. Gland uptake after 24 hours $=25 \%$. 
TABLE 3

CASES OF PROGERIA WHOSE AGE AT THE TIME OF DEATH IS KNOWN

\begin{tabular}{|c|c|c|c|c|c|c|c|}
\hline \multirow{2}{*}{ No. } & \multirow{2}{*}{\multicolumn{2}{|c|}{$\begin{array}{l}\text { Authors } \\
\text { and Dates } \\
\text { Published }\end{array}$}} & \multirow{2}{*}{ Sex } & \multicolumn{3}{|c|}{ Evidence of Atheroma or Coronary Artery Disease } & \multirow{2}{*}{$\begin{array}{c}\text { Age at } \\
\text { Death } \\
\text { (in years) }\end{array}$} \\
\hline & & & & Clinical & E.C.G. & Necropsy & \\
\hline 1 & $\begin{array}{l}\text { Hutchinson } \\
\text { Gilford }\end{array}$ & $\begin{array}{l}(1886) \\
(1897)\end{array}$ & $\mathbf{M}$ & $\begin{array}{l}\text { Angina of effort, death } \\
\text { from 'syncope' }\end{array}$ & Not reported & Not done & 17 \\
\hline 2 & Gilford & (1897) & $\mathbf{M}$ & $\begin{array}{l}\text { Choking sensation on } \\
\text { exertion }\end{array}$ & Not reported & $\begin{array}{l}\text { Atheroma; both coro- } \\
\text { nary arteries occluded }\end{array}$ & 18 \\
\hline 3 & $\begin{array}{l}\text { Variot } \\
\text { Variot and Pironneau }\end{array}$ & $\begin{array}{l}(1921) \\
(1910)\end{array}$ & $\mathbf{F}$ & No clinical history ava & ble following descrip & n of child at 15 years & 22 \\
\hline 4 & $\begin{array}{l}\text { Schippers } \\
\text { Manschot }\end{array}$ & $\begin{array}{l}(1916) \\
(1950)\end{array}$ & $\mathbf{M}$ & Nocturnal dyspnoea & Positive & Atheroma, coronary & 27 \\
\hline 5 & Orrico and Strada & (1927) & $\mathbf{M}$ & $\begin{array}{l}\text { Hemiplegia at } 19 \text { years, } \\
\text { sudden death }\end{array}$ & Not reported & Widespread atheroma & 21 \\
\hline 6 & Curtin and Kotzen & (1929) & $\mathbf{F}$ & $\begin{array}{l}\text { Angina, died from } \\
\text { coronary thrombosis }\end{array}$ & $\begin{array}{c}\text { Negative at an } \\
\text { early age }\end{array}$ & Not done & 9 \\
\hline 7 & Talbot et al. & $(1945)$ & $\mathbf{M}$ & Angina of effort & Normal at 6 years & $\begin{array}{l}\text { Generalized atheroma, } \\
\text { myocardial infarcts }\end{array}$ & 7 \\
\hline 8 & $\begin{array}{l}\text { Schwartz and Cooke } \\
\text { Cooke }\end{array}$ & $\begin{array}{l}(1945) \\
(1953)\end{array}$ & $\mathbf{M}$ & Angina of effort & Positive & Not done & 8 \\
\hline $\begin{array}{r}9 \\
10\end{array}$ & $\begin{array}{l}\text { Cooke } \\
\text { Atkins }\end{array}$ & $\begin{array}{l}(1953) \\
(1954)\end{array}$ & $\begin{array}{l}\mathbf{F} \\
\mathbf{M}\end{array}$ & $\begin{array}{l}\text { Angina of effort } \\
\text { Nocturnal dyspnoea, } \\
\text { myocardial infarct }\end{array}$ & $\begin{array}{l}\text { Not reported } \\
\text { Positive }\end{array}$ & $\begin{array}{l}\text { Not done } \\
\text { Atheroma, myocardial } \\
\text { infarct }\end{array}$ & $\begin{array}{l}13 \\
11\end{array}$ \\
\hline
\end{tabular}

Biopsy of Skin from Abdominal Wall. The epidermis was normal apart from wrinkling. The pigmentation was by melanin in the basal cells of the epidermis; it was unequally distributed and definitely in excess in some areas. There was no flattening of the interpapillary ridges. Elastic tissue was rather more plentiful and in coarser fibres in the dermis than in a control of the same age. The arrectores pilorum muscles were large and conspicuous, although hair follicles were scanty. There was no evidence of scleroderma or of senile elastosis.

\section{Discussion}

One of the most extraordinary features of progeria is the early development of atherosclerosis, the occurrence of which during the first two decades of life must always warrant serious consideration. Of the 24 reported cases of progeria the age of death is known in 10 (Table 3). In five of these the results of necropsy have been published and all have shown evidence of widespread and advanced atherosclerosis and in four occlusions of the coronary arteries and myocardial infarcts were demonstrated. Moreover, of the five cases on which necropsies were not performed, four are recorded as experiencing angina pectoris, in one of which an electrocardiogram suggested myocardial infarction. No details are available concerning the last seven years of life of the remaining case (Variot and Pironneau, 1910; Variot, 1921). The earliest age at which any clinical manifestations of coronary sclerosis have been reported in a case of progeria is 7 years (Talbot, Butler, Pratt, MacLachlan and Tannheimer, 1945).

There is now little doubt that in the adult coronary sclerosis is associated with a disturbance of lipid metabolism and that this disturbance is reflected by abnormalities in the circulating lipids and lipoproteins (Gertler, Garn and Lerman, 1950; Russ, Eder and Barr, 1951; Steiner, Kendall and Mathers, 1952; Oliver and Boyd, 1953, 1955). Cholesterol measurements have been recorded in seven cases of progeria; these measurements, together with any clinical or post-mortem evidence of atherosclerosis, are shown in Table 4 . There is no indication in most of these reports of the methods of estimation which were employed or the normal range of the laboratories concerned. In the present case a more complete analysis of the circulating lipids and lipoproteins has been possible (Table 2). The plasma total cholesterol level is elevated above the normal range determined in the same laboratory, but more significant is the elevation of the ratio of

TABLE 4

CHOLESTEROL LEVELS IN CASES OF PROGERIA

\begin{tabular}{|c|c|c|c|c|}
\hline $\begin{array}{l}\text { Authors } \\
\text { and Date }\end{array}$ & & $\begin{array}{l}\text { Age of Patient } \\
\text { (in years) }\end{array}$ & $\begin{array}{l}\text { Cholesterol } \\
\text { (mg./100 ml.) }\end{array}$ & $\begin{array}{l}\text { Evidence of } \\
\text { Atherosclerosis }\end{array}$ \\
\hline $\begin{array}{l}\text { Exchaquet } \\
\text { Zeder } \\
\text { Talbot } \text { et al. } \\
\text { Thomson and Forfar } \\
\text { Rossi } \\
\text { Atkins } \\
\text { Plunkett } \text { et al. }\end{array}$ & $\begin{array}{l}(1935) \\
(1940) \\
(1945) \\
(1950) \\
(1951) \\
(1954) \\
(1954)\end{array}$ & $\begin{array}{c}14 \\
5 \\
6 \\
4 \\
3 \\
3-11 \\
4-17\end{array}$ & $\begin{array}{c}270 \\
327 \\
170-300 \\
275 \\
294 \\
240-287 \\
218\end{array}$ & $\begin{array}{l}\text { Not reported } \\
\text { Not reported } \\
\text { Atheroma at necropsy } \\
\text { None clinically } \\
\text { Not reported } \\
\text { Atheroma at necropsy } \\
\text { None clinically }\end{array}$ \\
\hline
\end{tabular}


total cholesterol to total circulating phospholipids (the $\mathrm{C} / \mathrm{P}$ ratio) and the abnormally high concentration of cholesterol on the beta-lipoprotein fraction. Such a combination of abnormalities is most uncommon in the adult in the absence of overt coronary sclerosis, xanthomatosis, essential hyperlipaemia, or myxoedema, and presumably very rare at the age of 3 . It is interesting that Mitchell and Goltman (1940) report and reproduce a photograph of a cutaneous xanthomatous plaque in a child with progeria aged 10 years.

The genesis of progeria has frequently been related to endocrine dysfunction. It is known that many hormones influence the circulating lipids and lipoproteins, and the demonstration of an abnormal lipid and lipoprotein pattern in the early years of a patient with progeria is not necessarily inconsistent with an elusive endocrine disorder. However, the results of the series of tests undertaken in this child suggest that he is not suffering from any gross upset of endocrine function.

That progeria and atherosclerosis are closely associated would appear evident from the records of previous cases. The abnormal circulating lipid and lipoprotein pattern in this 3-year-old child might possibly be regarded as circumstantial evidence for the presence of coronary sclerosis despite the absence of supporting clinical manifestations. The premature development of atherosclerosis in progeria may possibly be similar in character to its development in the adult, except that the metabolic errors are perhaps inborn in the former and acquired in the latter. By the study of the rapid development of atherosclerosis in the rare cases of progeria, it is possible that further information may be forthcoming to those concerned with its pathogenesis in adults.

Interest in possible pituitary dysfunction has tended to overshadow the presence of atherosclerosis in investigations into the aetiology of progeria. Variot and Pironneau (1910), however, impressed by the report of atherosclerosis in the necropsy on Gilford's case (Gilford, 1897), suggested that it might play an important role in the pathogenesis of this condition. It is tempting to support this view, but at present the aetiology of progeria must remain obscure.

\section{Summary}

The clinical features of progeria in a boy of 3 years are described. No evidence of endocrine dysfunction was detected. The pattern of the circulating lipids and lipoproteins was similar to that of an adult with overt coronary sclerosis. The relationship between progeria and the premature development of atherosclerosis is discussed. It is suggested that further study of this association might be rewarding.

We should like to thank Dr. D. N. Nicholson for permission to publish this case, which was under his care, and for his help in the preparation of the paper.

We are also grateful to Professor R. W. B. Ellis, Dr. Rae Gilchrist and Professor G. F. Marrian, F.R.S., for their advice.

\section{REFERENCES}

Allen, R. J. L. (1940). Biochem. J., 34, 858

Atkins, L. (1954). New Engl. J. Med., 250, 1065.

Boyd, G. S. (1954). Biochem. J., 58, 680.

Cooke, J. V. (1953). J. Pediat., 42, 26.

Curtin, V. T. and Kotzen, H. F. (1929). Amer. J. Dis. Child., $38,993$.

Doub, H. P. (1953). Med. Radiogr. Photogr., 29, 60.

Exchaquet, L. (1935). Rev. franc. Pédiat., 11, 467.

Gertler, M. M., Garn, S. M. and Lerman, J. (1950). Circulation, 2,205

Gilford, H. (1897). Med.-chir. Trans., 80, 17.

(1902). Brit. med. J., 2, 1408.

Hutchinson, J. (1886). Med.-chir. Trans., 69, 473.

Lloyd, C. W. and Lobotsky, J. (1950). J. clin. Endocr., 10, 1559.

Manschot, W. A. (1950). Acta paediat., Uppsala, 39, 158.

Mitchell, E. C. and Goltman, D. W. (1940). Amer. J. Dis. Child., $59,379$.

Oliver, M. F. and Boyd, G. S. (1953). Brit. Heart J., 15, 387.

Orri (1955). Ibid., 17, 299 .

Orrico, J. and Strada, F.'(1927). Arch. Méd. Enf., 30, 385.

Plunkett, E. R., Sawtelle, W. E. and Hamblen, E. C. (1954). J. clin. Endocr. Metab., 14, 735.

Rossi, E. (1951). Helv. paediat. Acta, 6, 165.

Russ, E. M., Eder, H. A. and Barr, D. P. (1951). Amer. J. Med., $11,468$.

Schippers, J. C. (1916). Ned. T. Geneesk., p. 2274.

Schwartz, A. S. and Cooke, J. V. (1945). Biol. Symp., 11, 96.

Sperry, W. M. and Webb, M. (1950). J. biol. Chem., 187, 97.

Steiner, A., Kendall, F. E. and Mathers, J. A. L. (1952). Circulation, 5,605 .

Talbot, N. B., Butler, A. M., Pratt, E. L., MacLachlan, E. A. and Tannheimer, J. (1945). Amer. J. Dis. Child., 69, 267.

- Sobel, E. H., McArthur, J. W. and Crawford, J. D. (1952) Functional Endocrinology from Birth Through Adolescence. Cambrional Endocs.

Thomson, J. and Forfar, J. O. (1950). Archives of Disease in Childhood, 25, 224.

Variot, G. (1921). Maladie des Enfants, p. 1021. Paris.

Zeder, E. (1940). Mschr. Kinderheilk., 81, 167. 705. 